\title{
Antimicrobial effects of cellulose derivatives in the prevention of surgical infections: in vitro activity against- resistant microorganisms
}

\author{
Hafida Khorsi-Cauet ${ }^{1}$, Misbaou Barry ${ }^{2}$, Gilles Touati ${ }^{2}$, Hamdad Farida ${ }^{3}$, Véronique Bach ${ }^{1}$ and Maurice Biendo ${ }^{1 *}$ \\ ${ }^{1}$ Laboratoire Péritox INERIS UMR 101 CURS-UPJV, F-80054, AMIENS Cédex 1, France \\ ${ }^{2}$ Service de Chirurgie Cardiaque-CHU Amiens- Picardie Site SUD F-80054 AMIENS - Cédex 1, France \\ ${ }^{3}$ Laboratoire de Bactériologie-Centre de Biologie Humaine - CHU, Amiens Picardie, Site SUD F 80054 - AMIENS - Cédex 1, France
}

\begin{abstract}
Background: Wound healing is a dynamic and complex process which requires suitable environment to promote healing process. The aim of the study was to compare the in vitro antimicrobial effectiveness of iodine containing or note cellulose derivative dressings against five multi-drug resistant bacteria hospital strains.

Methods: Six cellulose derivative dressings with or without povidone iodine added were inoculated with five multi-drug resistant bacteria strains and reference strains. Culture protocol was carried out, then plates were examined for bacterial growth after incubation. The presence of a zone of inhibition, both underneath and around the dressing was assessed. In addition, the remaining bacteria on the cellulose derivative dressings were quantified by the CFU assay Statistical analysis was performed, and results were recorded.

Results: The statistical results showed that, the antimicrobial efficacy of cellulose derivative without and with povidone iodine depends of the strain origin ( $p=0.02$ ); an average diameter of inhibition is smaller by $7.7 \mathrm{~mm}$ for a hospital strains compared to reference strains; the in vitro antimicrobial activity of the cellulose derivative without and with povidone iodine compared to oxidized regenerated cellulose without povidone iodine used as a reference showed $p<0.0001$, indicating that all treatments were significant; no cells $\left(1 \times 10^{\circ} \mathrm{CFU} / \mathrm{mL}\right)$ were found on CMC $294+10 \%$ PVI and ORC+10\% PVI for reference bacteria and ORC+10\% PVI for hospital bacteria.
\end{abstract}

Conclusion: These results suggest a synergistic effect of the combination cellulose derivative-povidone iodine on the different hospital bacteria tested. ORC+10\% PVI is effective at killing hospital bacterial strains $\left(1 \times 10^{\circ} \mathrm{CFU} / \mathrm{mL}\right)$.

\section{Background}

All wounds are generally colonized with microorganisms, often without clinical consequence, and the presence of some microorganisms may even aid healing. However, contamination with pathogenic microbial flora can lead to infection and sepsis which disrupts the healing continuum. The development of infection is determined by complex interactions between the host and microorganisms. It is further influenced by the environment and therapeutic interventions [1].

Poor wound healing and postoperative surgical site infection (SSI) continues to be one of the most common complication in surgery, with an incidence in the literature varying from 2.5 to $17 \%$ [2]. This incidence depends on the type of surgery (cardiac, digestive, orthopedic or other) and the degree of superficial or deep infection.

The emergence of multi-drug resistant (MDR) microorganisms presents a critical problem for patients undergoing surgery. The postoperative infection is currently the leading cause of morbidity and mortality in surgery despite the development of antibiotics, improved techniques of anaesthesiology, and progress in preventive measures of hygiene. This is due to practice of surgical procedures increasingly targeting patients with more severe conditions and who are often immunocompromised.
Deep SSI requires reoperation, usually leading to prolonged hospitalization and morbidity, carrying substantially increased hospital and social costs. Several risk factors for the development of an SSI have been identified, including steroid use, smoking, long operating times, and complicated procedures [3] as well as underlying comorbidities [4]. Because of the seriousness of this complication, surgeons are continually looking for ways to decrease the rate of postoperative infection [5,6]. Few antimicrobial substances are generally considered for wound therapy. Of these, cellulose derivative (CD) dressings containing $10 \%$ povidone-iodine (PVI) [betadine] is widely accepted as the main antisepsis used to decrease the infectious risk.

The aim of this study was to compare the in vitro antimicrobial activity of a range of antimicrobial CD dressings, with or without added iodine, against five hospital MDR bacterial strains. It was also

*Correspondence to: Maurice Biendo, Laboratoire Péritox INERIS UMR 101 CURS UPJV F-80054 Amiens-Cédex 1, France, E-mail: maurice.biendo@u-picardie.fr

Key words: cellulose derivative, multi-drug resistant, povidone iodine, oxidized regenerated cellulose

Received: September 05, 2020; Accepted: September 15, 2020; Published: September 17, 2020 
undertaken to measure the effectiveness of $\mathrm{CD}$ dressings with and without $10 \%$ PVI.

\section{Materials and methods \\ Cellulose derivative dressings and antiseptic}

The dressing evaluated contained sodium carboxymethyl cellulose (Na-CMC) 282 and CMC 294 provided by Dina-Hitex (Bučovice Czech Republic); oxidized regenerated cellulose (ORC) provided by Ethicon Laboratory (Issy-les-Moulineaux, France). The antiseptic used in this study is povidone iodine (PVI) solution (Betadine) containing 10\% iodine (Laboratory Meda Pharma, France). The choice of this antiseptic is based on the fact that it is the most widely accepted as the main antiseptic used in surgery because of its antibacterial activity.

\section{Control and dressing tests}

The control wound dressings were comprised of a sterile gauze compress (SGC) $+100 \mu \mathrm{L}$ of $10 \% \mathrm{PVI}$ as an $\mathrm{I}_{2}$ positive control, Na-CMC 282 ,Na-CMC $282+100 \mu \mathrm{L}$ of $10 \%$ PVI ;CMC 294,CMC $294+100 \mu \mathrm{L}$ of $10 \% \mathrm{PVI}$;and ORC,ORC $+100 \mu \mathrm{L}$ of $10 \% \mathrm{PVI}$ as dressing tests.

\section{Bacterial strains}

The two types of bacterial strains were used for this study. The reference strains: Enterococcus hirae CIP 58.55; Staphylococcus hominis ATCC 27844; methicillin susceptible Staphylococcus aureus CIP 4.83 (MSSA); Staphylococcus epidermidis ATCC 14990; Escherichia coli CIP 54.127. The hospital strains, for which antimicrobial susceptibility testing had already been performed, were from a frozen stock of bacteria in the APUH clinical bacteriology department and were selected according to their resistance phenotype: Glycopeptide resistant Enterococcus faecalis (GREfae); glycopeptide resistant Enterococcus faecium (GREfam); methicillin resistant Staphylococcus aureus (MRSA); extended spectrum $\beta$-lactamase (ESBL)-Enterobacter aerogenes; MDR Pseudomonas aeruginosa. The reference and MDR strains were maintained on a Mueller-Hinton $(\mathrm{MH})$ medium enriched with horse serum, then seeded into storage tubes which were stored at $-20^{\circ} \mathrm{C}$.

\section{Test method}

The PVI square dressings were prepared by adding $100 \mu \mathrm{L}$ of $10 \%$ PVI solution onto each square dressing measuring $4 \mathrm{~cm}^{2}(2 \mathrm{~cm} \times 2 \mathrm{~cm})$.

Briefly, bacteria were cultured in parallel (reference and hospital strains) on Columbia agar with $5 \%$ horse blood and incubated in aerobic conditions at $35 \pm 2^{\circ} \mathrm{C}$ for 24 hours. From a colony, a bacterial suspension was prepared in saline $0.85 \% \mathrm{NaCl}$. The bacterial density was adjusted to match a $0.5 \mathrm{McF}$ arland standard (approximately $10^{7}$ Colony Forming Unit (CFU)/mL using a densitometer (BioMérieux, Marcy l'Etoile, France). Following this, a sterile cotton swab was dipped into $10^{7} \mathrm{CFU} / \mathrm{mL}$ of the bacterial suspensions. Within $15 \mathrm{~min}$ after the $5 \%$ blood Columbia agar (BCA) plates were inoculated, PVI square dressings were placed towards the center of an agar plate to allow for development of a zone of inhibition (ZOI). All plates were incubated aerobically at $35 \pm 2^{\circ} \mathrm{C}$ for 24 hours. Following incubation, the plates were examined for bacterial growth and the presence of a ZOI. The diameters of the zones of complete inhibition, including the diameter of the dressing square, were measured to the nearest $\mathrm{mm}$ with a ruler. The ZOI for each dressing corresponding to each tested strain was calculated and recorded. In addition, all experiments were done in triplicate, and all measurements were repeated three times.

\section{Colony forming unit assay}

We analysed the remaining bacteria on the square $\mathrm{CD}$ dressings using the CFU/mL assay as previously described [5,6] with some modifications. All experiments were also done in triplicate.

Briefly, bacteria were grown overnight in brain heart infusion (BHI) broth at $35 \pm 2^{\circ} \mathrm{C}$. After this incubation, the bacteria culture was washed in $\mathrm{MH}$ broth and the bacterial suspension was adjusted to 0.5 MacFarland as described above. Following this, a sterile cotton swabs was dipped into the adjusted bacterial culture, and a lawn of bacteria was made on a BCA using the dipped swab). The bacteria were then allowed to grow for 24 hours at $35 \pm 2^{\circ} \mathrm{C}$. The $\mathrm{CD}$ dressings with and without PVI were distributed evenly onto the BCA surface. Following incubation for 24 hours at $35 \pm 2{ }^{\circ} \mathrm{C}$, each $\mathrm{CD}$ dressing was transferred to be sterile $1.5-\mathrm{mL}$ micro centrifuge tube containing $1 \mathrm{~mL}$ of PBS ( $\mathrm{pH}=7.4)$ for enumeration of bacteria. The tubes were placed in water bath sonicator for $10 \mathrm{~min}$ to loosen the cells within the CD dressings and then vigorously vortexed 3 times for $1 \mathrm{~min}$ to detach the cells. Suspended cells were serially diluted (10-fold) in PBS, and $10-\mu \mathrm{L}$ aliquots of each dilution were spotted onto BCA plates. In addition, the remained $900 \mu \mathrm{L}$ zero dilution sample was also plated on a different BCA plate. Thus, the equation for calculating the bacterial concentration was: $\mathrm{CFU}=$ number of colonies $\mathrm{X}$ dilution factor/ inoculum volume in $\mathrm{mL}$. This means that if only one bacterial cell was originally in the tube, we would have a $90 \%$ chance of detecting it. All experiments were repeated 3 times with $7 \mathrm{CD}$ dressings each time. Thus, there were 21 separate determinations for each combination tested.

\section{Statistical analysis}

For analysis of variance, Student's t-test was used to determine whether there was a significant difference between the dressing test and their effect against the different bacteria. Differences were considered significant when the $p$-value was $<0.05$. If no significant difference was observed, the ZOI surrounding antimicrobial dressings against hospital strains were compared by multivariate analysis using the MIXED Procedure. The limit of significant was used to assess the heterogeneity of different hospital bacteria compared to the study of efficacy $(\mathrm{P}<0.05)$.

\section{Results}

\section{Activity of CD actions without and with 10\% PVI against reference and hospital bacterial strains}

The cellulose derived dressings containing the reference strains without PVI showed a mean ZOI of $15.0 \mathrm{~mm}$ and the mean of those with PVI was $24.1 \mathrm{~mm}$ versus $10.2 \mathrm{~mm}$ for PVI alone (Table 1). In hospital strains, The CDs without PVI showed a mean ZOI of $8.6 \mathrm{~mm}$ and the mean of those with PVI was $15.2 \mathrm{~mm}$ versus $0 \mathrm{~mm}$ for SGC + PVI alone (Table 2). These two results show a synergic effect of $10 \%$ PVI with the content of CD. The average diameter of inhibition for hospital strains was $7.7 \mathrm{~mm}$ smaller than that of reference strains.

\section{Effect of $10 \%$ PVI treatment on reference and hospital bacterial strains for in vitro CFU studies}

The results for the 24 hours in vitro CFU studies in the presence of CD dressings without and with 10\% PVI using reference strains and hospital bacterial strains are illustrated in Figure 1. When the CDs were tested for bacteria after the ZOI studies were completed using CFU assays, an average of $1.0 \times 10^{5} \mathrm{CFU} / \mathrm{mL}$ was found on SGC+10\% PVI versus $8.0 \times 10^{4}$ and $2.0 \times 10^{4} \mathrm{CFU} / \mathrm{mL}$ found on CDs with and without $10 \%$ PVI for reference bacterial strains and between $1.2 \times 10^{5}$ and $1.0 \times 10^{4}$ 
Table 1. The mean zones of inhibition (ZOI) observed with cellulose derivatives with and without $5 \%$ PVI and reference strains $\left({ }^{\mathrm{a} C I P}\right.$ : Collection Institut Pasteur strain; ${ }^{\mathrm{b}} \mathrm{Coagulase}$ negative Staphylococcus strain :American type culture collection oxacillin/cefoxitine susceptible ; ${ }^{\mathrm{c}} \mathrm{MSSA}$ :methicillin susceptible Staphylococcus aureus ; $\mathrm{PVI}$ : povidone-iodine (Betadine); ${ }^{\mathrm{e}} \mathrm{CMC}$ : carboxymethyl cellulose; $\varnothing(\mathrm{mm})$ :inhibition diameter .ZOI (zone of inhibition) surrounding antimicrobial dressings. The CD dressings without $10 \%$ PVI showed a mean ZOI of $8.6 \mathrm{~mm}$ and the mean of those with $10 \%$ PVI was $15.2 \mathrm{~mm}$ versus $10.2 \mathrm{~mm}$ for $10 \%$ PVI alone.These results indicate synergistic effect.The values of inhibition diameter represent the mean of triplicate experiments)

\begin{tabular}{|c|c|c|c|c|c|c|c|}
\hline \multirow[b]{2}{*}{ Reference strains } & \multirow{2}{*}{$\begin{array}{c}\begin{array}{c}\text { Sterile gauze compress } \\
\text { (SGC) }\end{array} \\
\text { SGC }+100 \mu \mathrm{L} \\
\text { Of } 10 \% \text { dPVI }\end{array}$} & \multicolumn{6}{|c|}{ Cellulose derivatives } \\
\hline & & $\begin{array}{c}\text { Na- }{ }^{e} \mathrm{CMC} 282 \\
\left({ }^{\mathrm{f}} 囚 \mathrm{~mm}\right)\end{array}$ & $\begin{array}{c}\text { Na-CMC } 282+100 \mu \mathrm{L} \text { of } \\
10 \% \text { PVI }(\varnothing \mathrm{mm})\end{array}$ & $\begin{array}{l}\text { CMC } 294 \\
(\varnothing \mathrm{mm})\end{array}$ & $\begin{array}{c}\text { CMC } 294+ \\
100 \mu \mathrm{L} \\
\text { Of } 10 \% \text { PVI } \\
(\varnothing \mathrm{mm})\end{array}$ & $\begin{array}{c}\text { Oxidized and regenerated } \\
\text { cellulose (ORC) } \\
(\varnothing \mathrm{mm})\end{array}$ & $\begin{array}{c}\text { ORC }+100 \\
\mu \mathrm{L} \\
\text { of } 10 \% \mathrm{PVI} \\
(\varnothing \mathrm{mm})\end{array}$ \\
\hline $\begin{array}{c}\text { Enterococcus hirae } \\
{ }^{\mathrm{a}} \mathrm{CIP} 58.55\end{array}$ & 6 & 10.0 & 20.0 & 11.0 & 22.0 & 21.0 & 32.0 \\
\hline $\begin{array}{c}\text { S.hominis } \\
\text { bATCC27844 }\end{array}$ & 12 & 8.0 & 21.0 & 12.0 & 25.0 & 22.0 & 25.0 \\
\hline $\begin{array}{c}\text { 'S.aureus (MSSA) } \\
\text { CIP } 4.83\end{array}$ & 10 & 11.0 & 15.0 & 13.0 & 27.0 & 21.0 & 29.0 \\
\hline $\begin{array}{l}\text { S.epidermidis } \\
\text { ATCC } 14990\end{array}$ & 12 & 6.0 & 18.0 & 14.0 & 19.0 & 22.0 & 25.0 \\
\hline $\begin{array}{l}\text { Escherichia coli } \\
\text { CIP 54.127 }\end{array}$ & 11 & 14.0 & 20.0 & 11.0 & 25.0 & 30.0 & 39.0 \\
\hline Mean inhibition diameters & 10.2 & 9.8 & 18.8 & 12.2 & 23.6 & 23.2 & 30.0 \\
\hline
\end{tabular}

Table 2. The mean zones of inhibition (ZOI) observed with cellulose derivatives without and with $5 \%$ PVI and hospital strains ( ${ }^{a}$ Enterococcus faecalis; ${ }^{b}$ GRE: glycopeptide resistant Enterococcus; ${ }^{\mathrm{c}}$ Enterococcus faecium; ${ }^{\mathrm{d}}$ MRSA: methicillin resistant Staphylococcus aureus; ${ }^{\mathrm{e}}$ Enterobacter aerogenes; ${ }^{\mathrm{f}}$ ESBL: extended spectrum B-lactamase; ${ }^{g} P$ seudomonas aeruginosa. ; $\mathrm{mm}$ : zone of inhibition (ZOI) surrounding antimicrobial dressings against E.faecalis, E.faecium, MRSA, ESBL E.aerogenes, P.aeruginosa.The $10 \%$ PVI alone showed no ZOI against all hospital bacterial strains, however, $10 \%$ PVI in the cellulose derivatives showed ZOI against these bacteria,which is in favor of a synsergistic effect.The CD dressings without $10 \%$ PVI showed a mean ZOI of $8.6 \mathrm{~mm}$ and the mean of those with PVI was $15.2 \mathrm{~mm}$ versus $0 \mathrm{~mm}$ for $10 \%$ PVI alone.The values of inhibition diameter represent the mean of triplicate experiments)

\begin{tabular}{|c|c|c|c|c|c|c|c|}
\hline \multirow[b]{2}{*}{ Hospital strains } & \multirow{2}{*}{$\begin{array}{c}\text { Sterile gauze compress } \\
\text { (SGC) } \\
\\
\text { SGC }+100 \mu \mathrm{L} \\
\text { of } 10 \% \text { PVI }\end{array}$} & \multicolumn{6}{|c|}{ Cellulose derivatives } \\
\hline & & $\begin{array}{l}\text { Na-CMC } 282 \\
(\varnothing \mathrm{mm})\end{array}$ & $\begin{array}{c}\mathrm{Na}-\mathrm{CMC} 282+100 \mu \mathrm{L} \text { of } \\
10 \% \text { PVI }(\varnothing \mathrm{mm})\end{array}$ & $\begin{array}{l}\text { CMC } 294 \\
(\text { Ø mm })\end{array}$ & $\begin{array}{c}\text { CMC } 294+ \\
100 \mu \mathrm{L} \\
\text { Of } 10 \% \mathrm{PVI} \\
(\varnothing \mathrm{mm})\end{array}$ & $\begin{array}{l}\text { Oxidized and regenerated } \\
\text { cellulose (ORC) } \\
(\varnothing \mathrm{mm})\end{array}$ & $\begin{array}{c}\text { ORC }+100 \\
\mu \mathrm{L} \\
\text { of } 10 \% \mathrm{PVI} \\
(\varnothing \mathrm{mm})\end{array}$ \\
\hline${ }^{a}$ E.faecalis ( $\left({ }^{\mathrm{b}}\right.$ GEfae) & 0 & 7.0 & 10.0 & 8.0 & 15.0 & 11.0 & 20.0 \\
\hline${ }^{c}$ E.faecium (GREfam) & 0 & 6.0 & 11.0 & 7.0 & 14.0 & 12.0 & 18.0 \\
\hline S.aureus ( ${ }^{\mathrm{d}}$ MRSA) & 0 & 8.0 & 12.0 & 9.0 & 18.0 & 10.0 & 20.0 \\
\hline $\begin{array}{l}{ }^{e} \text { E.aerogenes } \\
\text { ('ESBL) }\end{array}$ & 0 & 10.0 & 14.0 & 10.0 & 15.0 & 11.0 & 21.0 \\
\hline${ }^{g}$ P.aeruginosa & 0 & 6.0 & 11.0 & 7.0 & 12.0 & 8.0 & 18.0 \\
\hline Mean inhibition diameters & 0 & 7.2 & 11.6 & 8.2 & 14.8 & 10.4 & 19.4 \\
\hline
\end{tabular}

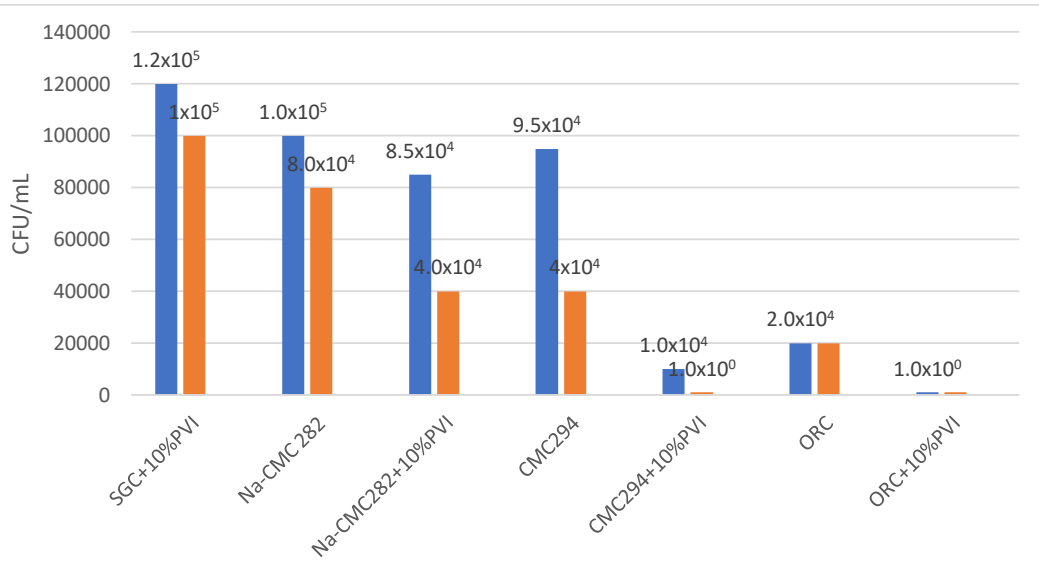

Blue: Hospital bacterial strains; Red:Reference bacterial strains

Figure 1. Blue: CFU assay results for the hospital bacterial strains

Glycopeptide resistant Enterococcus faecalis (GRFae); Glycopeptide resistant Enterococcus faecium (GFFam); Methicillin resistant Staphylococcus aureus (SARM); Extended spectrum B-lactamase (ESBL) Enterobacter aerogenes; Pseudomonas aeruginosa multi-drug resistant. The treatment samples were prepared as described in the Materials and Methods. All experiments were done in triplicate. The mean values were found on SGC and CD dressings without and with $10 \%$ PVI. However no cells were found on ORC+10\% PVI.

Red: The CFU assay results for the reference bacterial strains

Enterococcus hirae CIP 58.55; Staphylococcus hominis ATCC 27844; Methicillin susceptible Staphylococcus aureus (MSSA) CIP 4.83; Staphylococcus epidermidis ATCC 14990; Escherichia coli CIP 54.127. The treatment samples were prepared as described in the Materials and Methods. All experiments were done in tripilicate. The mean values were found on SGC and CD dressings without and with 10\% PVI. However no cells were found on CMC 294+10\% PVI and ORC+10\% PVI 
$\mathrm{CFU} / \mathrm{mL}$ for hospital bacteria. However, no cells $\left(1.0 \times 10^{\circ} \mathrm{CFU} / \mathrm{mL}\right)$ was found on CMC $294+10 \%$ PVI and ORC $+10 \%$ PVI for reference strains. No cells $\left(1.0 \times 10^{\circ} \mathrm{CFU} / \mathrm{mL}\right)$ was also found on ORC $+10 \%$ PVI for hospital bacterial strains showing the killing of bacteria on the CDs and demonstrating that the ZOI assay does not give a realistic assessment of the ability of an antimicrobial to kill bacteria.

\section{Statistical analysis results}

Analysis of all CD without and with PVI using student's t-test showed no significant difference in means for the number taken 2-2, probably because the studied numbers were insufficient to show a difference. However, MIXED Procedure test showed that Na-CMC 282 with and without PVI, CMC 294, and ORC with PVI $(\mathrm{p}<0.001)$, as well as CMC without PVI ( $\mathrm{p}=0.0461)$ were significant (Table 3$)$. The antimicrobial efficacy of CD without and with PVI depended on the strain origin (reference strains or MDR strains) $(\mathrm{P}=0.02)$. The in vitro antimicrobial activity of different $\mathrm{CD}$ without and with $\mathrm{PVI}$ compared to ORC without PVI used as a reference showed $\mathrm{P}<0.0001$, indicating that all treatments were significant. The inhibition diameter of ORC+PVI was significantly higher than ORC without PVI.

\section{Discussion}

Iodine is a nonmetallic essential nutrient with a potent broad range of microbicide act in against almost all of the important healthrelated microorganisms, including bacteria. Although a high content of iodine spp with free molecular form $\left(\mathrm{I}_{2}\right)$ and hypoiodous acid in aqueous solution has powerful microbicidal effects but can cause volatility, stinging and cytotoxicity. To overcome these problems, $I_{2}$ was combined with neutral carrier polymers to increase iodine solubility and to keep low the release of iodine as a solubilizing agent and to act as an iodine reservoir. The most popular carrier in current use is povidone, which has no microbicidal activity. Since povidone slowly and continuously releases $I_{2}$ into solution. The delivery of $I_{2}$ provides for the rapid antibacterial, antifungal and antiviral activity of PVI based disinfectants [7]. $\mathrm{I}_{2}$ acts on bacterial cells via oxidative degradation of cell components by damaging proteins, nucleotides and fatty acids, leading to rapid cell death [8]. The proteins and enzymes are denatured by binding to thiol and sulphydryl groups, and alters phospholipid membrane structures by blocking hydrogen bonding [9]. In addition, cytosolic enzymes involved in the respiratory chain are denatured and deactivated by $\mathrm{I}_{2}[9]$.

Povidone iodine (PVI) (Betadine) is a widely used antiseptic because it has particularly broad spectrum of antimicrobial activity that includes Gram-positive and Gram-negative bacteria [7,9,10]. However, many studies have shown the inefficacy of PVI solution against different bacteria $[11,12]$. Our results, as seen in Table 2 confirm that PVI along (SGC+10\% PVI) is very poor at inhibitjng the growth of MDR bacteria in vitro. It did not appear to show any ZOI in the hospital bacterial strains. According to data in the literature, the bacteria do not develop resistance to PVI [13], and the resistance rate to this product is only $0.7 \%$ [14]. This resistance was dependent on temperature, contact between PVI and bacterial suspension, concentration of disinfectant, and time of exposure.

We also tested Na-CMC 282, CMC 294, and ORC with and without $10 \%$ PVI which have been widely used for producing hydrogels and have been developed in many fields, including wound dressings. NaCMC and CMC dressings absorb and interact with wound exudates to form a soft, hydrophilic, gas permeable gel that traps bacteria and conforms to the contours of the wound. This is suitable for providing a microenvironment that is believed to facilitate healing in the presence of sodium ions from wound exudates. PVI can be impregnated into hydrogels which can be used for wound dressings. The rate of release of the iodine in the PVI is heavily dependent on the hydrogel composition. The release rate increases with more CMC and decreases with more gelatine. The iodine ions are released from $\mathrm{Na}-\mathrm{CMC}$ and $\mathrm{CMC}$ to exert a sustained antimicrobial effect against a wide range of organisms, including MRSA, E. coli and GRE, thus preventing colonization of the dressing and providing an antimicrobial barrier to protect the wound.

The ability of ORC to stimulate the growth of human dermal fibroblast and to inactivate elastase, has been assessed in the patients treated with combination collagen/ORC. This combination can inactivate potentially harmful factors such as proteases, oxygen free radicals and excess metal ions present in chronic wound fluid. It has been demonstrated that the acidic $\mathrm{pH}$ of ORC about 2.5 has a broadspectrum physiological detrimental to survival of microorganisms known to cause infections $[15,16]$. The present study showed that ORC has a strong antibacterial activity which is most evident when it is associated with PVI. The results of this in vitro association may be regarded as synergistic and support the hypothesis that the antimicrobial activity of ORC is effective against antibiotic-resistant microorganisms as described elsewhere [17]. The mode of antimicrobial action of the ORC is unclear. It has been shown that, in vitro, most of the ORC activity can be blocked by adding sodium hydroxide to the system [18]. Nevertheless, a pure $\mathrm{pH}$ effect would not explain the varying results which ORC has in vitro against different species of microorganisms

Table 3. Multivariate analysis using MIXED procedure test

\begin{tabular}{|c|c|c|c|c|c|}
\hline $\begin{array}{l}\text { Subjects and cellulose } \\
\text { derivative treatments }\end{array}$ & Estimated value & Error type & DDL & t value & P value \\
\hline Bacteria & 3.3598 & 2.1685 & & 1.55 & ${ }^{1} 0.0606$ \\
\hline Hospital strains & 21.9000 & 1.1588 & 8 & 18.90 & ${ }^{2}<0.0001$ \\
\hline $\begin{array}{c}\text { Reference strains (CIP) } \\
\text { Na-CMC 282+PVI }\end{array}$ & $\begin{array}{l}-3.0000 \\
35.5000\end{array}$ & $\begin{array}{l}1.3142 \\
1.0723\end{array}$ & $\begin{array}{l}45 \\
45\end{array}$ & $\begin{array}{c}-2.28 \\
5.13\end{array}$ & $\begin{array}{l}{ }^{2} 0.0272 \\
<0.0001\end{array}$ \\
\hline Na-CMC 282 & -37.7000 & 1.0723 & 45 & -7.18 & $<0.0001$ \\
\hline CMC 294 + PVI & ${ }^{4} 9.0000$ & 1.0723 & 45 & 8.39 & $<0.0001$ \\
\hline CMC 294 & -42.2000 & 1.0723 & 45 & -2.05 & 0.0461 \\
\hline $\mathrm{ORC}+\mathrm{PVI}$ & ${ }^{5} 8.8000$ & 1.0723 & 45 & 8.21 & $<0.0001$ \\
\hline ORC & 0.000 & & & & \\
\hline
\end{tabular}

${ }^{1}$ The limit of significance to assess the heterogeneity of different bacteria included in the study showed a $p$ value $=0.0606$ (is not significant)

${ }^{2}$ The antimicrobial efficacy of CD with and without $5 \%$ PVI depended on the strain origin [hospital strains $(\mathrm{p}<0.0001)$ or reference strains $\left.(p=0.0272)\right]$.

${ }^{3}$ The positive inhibition diameter values of Na-CMC 282+PVI are higher compared to negative inhibition diameter values of Na-CMC 282 without PVI ( $\mathrm{p}<0.0001$ ).

${ }^{4}$ The positive inhibition diameter values of CMC 294+PVI are higher compared to negative inhibition diameter values of CMC 294 without PVI ( $p<0.0001$ ).

${ }^{5}$ The positive inhibition diameter values of ORC+PVI are higher compared to low positive inhibition diameter values of ORC without PVI $(p<0.0001)$.

Overall treatment is effective $(p<0.0001)$. The average diameter of inhibition for hospital strains was $3 \mathrm{~mm}$ smaller than that of CIP strains 
[15]. However, due to its acidic $\mathrm{pH}$, ORC is resistant to bacterial infection [15]. Several studies have found that ORC itself prevents infection $[19,20]$. Nevertheless, it is recognized that in vitro data cannot be directly extrapolated to clinical outcomes.

Despite a broad range of antimicrobial agents as well as commercially available antibiotics, successful management of bacterial infections is particularly challenging due to an increase in microbial resistance caused by the abuse of such drugs. Treatment of non-healing wounds presents a difficult dilemma because of failure to heal due to repeat tissue injury by bacterial contamination and altered physiological conditions. For this reason, the development of innovative biopolymers combined with silver nanoparticles (AgNPs) have potential applications as wound dressing materials and for skin tissue repair [21]. Sacco et al. [22] and Pelgrift et al. [23] have tested silver because it appears to use a different killing mechanism from PVI. It is believed that the killing mechanism is due to the binding of silver ions to bacterial proteins causing structural changes in the bacterial cellular membrane. Silver ions also can bind and denature DNA and RNA, inhibiting bacterial replication [24]. Silver is biologically active when it is soluble which is in ion form of $\mathrm{Ag}^{+}$and in metallic form $\mathrm{Ag}^{\mathrm{o}}$ present in nanocrystalline silver [25]. A comparison of silver ions versus nanocrystalline silver was carried out by Wright et al. [26]. They found that the nanocrystalline form was more effective than the ionic one. Other authors reported that antibacterial activity of all used antibiotic against MDR strains increased in the presence of AgNP $[27,28]$. In addition, the highest synergistic effect of AgNP was observed against this MDR strains [28].

Consequently, PVI has found broad application in medicine as a surgical scrub, for pre and postoperative skin cleansing as well as for treatment and prevention of infections in wound. It remains unclear whether the antibacterial mechanisms detected can be attributed to iodine alone or by its combination with CD dressings. A synergistic effect was observed in this combination.

\section{Study limitations}

The limitation of the present study was that only five species of bacteria and $6 \mathrm{CD}$ dressings impregnated with iodine were assessed, whereas a complex mix of species is likely to be present in a real wound. Moreover, although certain physical and chemical parameters were measured, this model in no way replicates all of the factors involved in a real wound bed in vivo, particularly the host response. Another limitation is the study performed was in vitro and may not mimic in vivo.

\section{Conclusions}

Antimicrobial properties of $\mathrm{I}_{2}$ have been used in preparation of wound dressing. It combination with $\mathrm{CD}$ dressings can be used in clinical and surgical practice and shows promising results in healing of contaminated contamined wounds. In this study, we noted that although overall treatment set used shows an ZOI around the CD dressings, differences were observed between the antimicrobial compounds, and a significant difference was shown between the dressings and their efficacy against each bacterial strain. This is most likely due to the structural properties of the individual dressing, affecting delivery of the compound. These results suggest that in vitro, $10 \% \mathrm{PVI}$ alone shows that the ZOI assay does not give a realistic assessment of the ability of an antimicrobial to kill bacteria, while in vitro ORC $+10 \% \mathrm{PVI}$ is only very effective against the MDR bacteria tested.

\section{Acknowledgments}

All authors thank Dr. Momar Diouf who participated in the study by carrying out the statistical analysis.

\section{Conflicts of interest}

None of the authors reported a conflict of interest related to the study.

\section{Ethics approval and consent to participate}

The present study was conducted according to the guidelines laid down in the Declaration of Helsinki, and all procedures were approved by the Ethics Committee for the Protection of Persons (CPP) of the Amiens-Picardie University Hospital (APUH) in the 2019 session (assessment $\mathrm{N}^{\circ} 139$ ).

\section{Consent for publication}

Not applicable.

\section{Authors' contribution}

The authors performed this research and wrote the manuscript.

\section{Funding sources}

This research did not receive any specific grant from funding agencies in the public commercial, or not-for-profit sectors.

\section{Availability of data and materials}

The dataset used and analyzed during this study is available from the authors on reasonable request.

\section{References}

1. Bigliardi PL, Alsagoff SAL, El-Kafrawi HY, Pyon JK,Wa CTC, et al. ( 2017) Povidone iodine in wound healing: A review of current concepts and practices. Int Surg 44: 260268. [Crossref]

2. Société Française Hygiène Hospitalière (S.F.2.H) (2010) Infections du site opératoire, Surveiller et prévenir les infections associées aux soins, pp : 111-113.

3. Finan KR, Vick CC, Kiefe CI, Neumayer L, Hawn HT, et al. (2005) Predictors of wound infection in ventral hernia repair. Am J Surg 190: 676-681. [Crossref]

4. Falagas ME, Kasiakou SK (2005) Mesh-related infections after hernia repair surgery Clin Microbiol Infect 11: 3-8.

5. Tran P, Hamood A, Mosley T, Gray T, Jarvis C, et al. (2013) Organo-seleniumcontaining dental sealant inhibits bacterial biofilm. J Dent Res 92: 461-466.

6. Tan P, Arnett A, Jarvis C, Mosley T, Tran K, et al. (2017) Organo-selenium coatings inhibit Gram-negative and Gram-positive bacterial attachment to ophthalmic scleral buckle material. Trans Vis Sci Tech 6: 1-8. [Crossref]

7. Pelletier J, Barone S, Capriotti j (2018) Efficacy of dilute povidone-iodine preparations against multi-drug resistant biofilms of Staphylococcus aureus, Klebsiella pneumoniae, Pseudomonas aeruginosa and Candida albicans. Clin Res Dermatol 7: 147-148.

8. McDonnell G, Russell AD (1999) Antiseptics and disinfectants:activity,action,and resistance. Clin Microbiol Rev 12: 147-179.

9. Kanagalingam JR, Feliciano R, Hah JH, Labis H, Le TA, et al. (2015) Practical use of povidone-iodine antiseptic in the maintenance of oral health and in the prevention and treatment of common oropharyngeal infection. Int J Clin Pract 69: 1247-1256. [Crossref]

10. Capriotti K, Pelettier J, Barone S, Capriotti J (2018) Efficacy of dilute povidone-iodine against multi-drug resistant bacterial biofilms,fungal biofilms and fungal spores. Clin Res Derm 5: 1-5.

11. Anderson RL, Vess RW, Panlilio AL, Favero MS (1990) Prolonged survival of Pseudomonas cepacian in commercially manufactured povidone-iodine. Appl Environ Microbiol 56: 3598-3600. [Crossref] 
12. Berkelman RL, Lewin S, Allen JR, Anderson RL, Budnick LD, et al. (1981) Pseudomonas attributed to contamination of povidone-iodine with Pseudomonas cepacian. Ann Intern Med 95: 32-36.

13. Alfieri S, Di Miceli D, Menghi R, Quero G, Cina C et al. (2011) Role of oxidized regenerated cellulose in preventing infections at the surgical site prospective, randomized study in 98 patients affected by a dirty wound. Minerva Chir 66: 55-62.

14. Niedner R (1997) Cytotoxicity and sensitization of povidone-iodine and other frequently used anti-infective agents. Dermatol 195 (Suppl 2): 89-92. [Crossref]

15. Cullen B, Watt PW, Lundqvist C, Silcock D, Schmidt RJ, et al. (2002) The role of oxidised regenerated cellulose/collagen in chronic wound repair and its potential mechanism of action. Int J Bioch Cell Biol 12: 1544-1556.

16. Dineen P (1976) Antibacterial activity of oxidized regenerated cellulose. Surg Gynecol Obstet 142: 481-486.

17. Spangler D, Rothenburger S, Nguyen K, Jampani H, Weiss S, et al. (2003) In vitro antimicrobial activity of oxidized regenerated cellulose against antibiotic-resistant microorganisms. Surg Infect 4: 255-262. [Crossref]

18. Thorn RMS, Austin AJ, Greenman J, Wilkins JP, Davis PJ, et al. (2009) In vitro comparison of antimicrobial activity of iodine and silver dressings biofilms. $J$ Wound Cares 18: 343-346.

19. Dineen P (1977) The effect of oxidized regenerated cellulose on experimental intravascular infection. Surg 82: 576-579. [Crossref]

20. Gottrup F, Cullen BM, Karlsmark T, Bischoff-Mikkelsen M, Nisbet L, et al. (2013) Randomized controlled trial on collagen/oxidized regenerated cellulose/silver treatment. Wound Repair Regen 21: 216-225.
21. Capanema NSV, Mansur AAP, Carvalho SM, Mansur LL, Ramos CP, et al. (2018) Physicochemical properties and antimicrobial activity of biocompatible carboxymethyl cellulose-silver nanoparticle hybrids for wound dressing and epidermal repair. $J$ Appl Polym Sci 135: 45812 .

22. Sacco P, Travan A, Borgogna M, Paoletti S, Marsich E, et al. (2015) Silver-containing antimicrobial membrane based on chitosan-TPP hydrogel for the treatment of wounds. J Mater Sci Med 26: 128.

23. Pelgrift RY, Friedman AJ (2013) Nanotechnology as a therapeutic tool to combat microbial resistance. Adv Drug Deliv Rev 65: 1803-1815. [Crossref]

24. Hiro Matthew E, Pierpont YN, Ko F, Wright TE, Robson MC, et al. (2012) Comparative evaluation of silver-containing antimicrobial dressings on In vitro and In vivo processes of wound healing. Eplasty 12: e48. [Crossref]

25. Konop M, Damps T, Misicka A, Rudnicka 1 (2016) Certain aspects of silver and silver nanoparticles in wound care:a minireview. J Nanomaterials.

26. Wright JB, Lam K, Burrell RE (1998) Wound management in an era of increasing bacterial antibiotic resistance a role for topical silver treatment. Am J Infect Control 26: 572-577. [Crossref]

27. Naqvi SZH, Kiran U, Ali MI, Jamal A, Hameed A, et al. (2013) Combined efficacy of biologically synthesized silver nanoparticles and different antibiotics against multidrugresistant bacteria. Intern J Nanomedicine 8: 3187-3195. [Crossref]

28. Thomas R, Nair AP, Mathew SKr, EK R (2014) Antibacterial activity and synergistic effect of biosynthesized AgNPs with antibiotics against multidrug-resistant bioforming coagulase-negative staphylococci isolated from clinical samples. Appl Bioch Biotech 173: 449-460. [Crossref]

Copyright: (C2020 Khorsi-Cauet H. This is an open-access article distributed under the terms of the Creative Commons Attribution License, which permits unrestricted use, distribution, and reproduction in any medium, provided the original author and source are credited. 